\title{
SWOT analysis of smart city projects in capital cities of Russia and Kazakhstan
}

\author{
M.T. Urdabayev $\bowtie$, R.E. Utkelbay
Al-Farabi Kazakh National University, Almaty, Kazakhstan; marat.urdabayev@ieconom.kz \\ M.T. Urdabayev $\bowtie$, R.E. Utkelbay
Al-Farabi Kazakh National University, Almaty, Kazakhstan; marat.urdabayev@ieconom.kz
}

\begin{abstract}
Relevance. Large-scale digitalization projects contribute to national economic development and to the improvement of the living standards in countries and regions. Cities with high population density and vibrant economic growth can benefit the most from such projects.

Research objective. This study aims to conduct a strategic analysis of smart city projects in capital cities of Russia and Kazakhstan (Moscow, Nur-Sultan, and Almaty).

Data and methods. The study provides an overview of academic and professional media publications on the topic, national and local official documents, materials reflecting expert discussions about the problems of smart city development in Russia and Kazakhstan. Methodologically, the study relies on SWOT-analysis methods used to systematize diverse empirical data and to provide evidence for managerial decision-making.

Results. In this study, we systematized the key approaches to the definition of a smart city and proposed our own interpretation of this term with a special emphasis on SWOT factors. The main digital services in Moscow, Nur-Sultan and Almaty were described. The results of SWOT analysis have shown some significant differences in the way the three capital cities implement their smart city projects as well as similar problems they are facing, such as the institutional barriers, the lack of standards, financial constraints, the shortage of domestically produced equipment and software, of highly qualified human resources, and private investors.

Conclusions. The range of factors that affect the implementation of smart city projects in the three cities include the COVID-19 pandemic, which is likely to stimulate the digital transformation both in the short and long term.
\end{abstract}

\section{KEYWORDS}

smart city, capital, SWOT analysis, comparative analysis, Russia, Kazakhstan

\section{ACKNOWLEDGEMENTS}

This research is funded by the Science Committee of the Ministry of Education and Science of the Republic of Kazakhstan (targeted funding program BR10965247 'Study of factors, features and dynamics of demographic processes, migration, urbanization in Kazakhstan, development of digital maps and forecasts')

\section{FOR CITATION}

Urdabayev, M.T., \& Utkelbay, R.E. (2021) SWOT analysis of smart city projects in capital cities of Russia and Kazakhstan. R-economy, 7(4), 235-243. doi: 10.15826/ recon.2021.7.4.021

\section{SWOT-анализ проектов smart-city в столичных городах России и Казахстана}

\section{М.Т. Урдабаев $\bowtie$, Р.Е. Уткелбай}

Казахский национальный университет имени аль-Фараби, Алматы, Казахстан; marat.urdabayev@ieconom.kz

\section{АННОТАЦИЯ}

Актуальность. Крупномасштабные проекты цифровизации способствуют развитию национальной экономики и повышению уровня жизни в странах и регионах. Города с высокой плотностью населения и динамичным экономическим ростом могут извлечь наибольшую выгоду из таких проектов.

Цель исследования - проведение стратегического анализа проектов «Умных городов», реализуемых в крупнейших столичных городах России и Казахстана (Москвы, Нур-Султана, Алматы)

Данные и методы. В исследовании представлен обзор публикаций академических и профессиональных СМИ по данной теме, национальных и местных официальных документов, материалов, отражающих экспертные дискуссии о проблемах развития умных городов в России и Казахстане. Методологически исследование опирается на методы SWOT-анализа, используемые для систематизации различных эмпирических данных и предоставления доказательств для принятия управленческих решений. Результаты. В данном исследовании мы систематизировали ключевые подходы к определению умного города и предложили собственную ин-

\section{КЛЮЧЕВЫЕ СЛОВА}

умный город, столица, SWOT-анализ, сравнительный анализ, Россия, Казахстан

\section{БЛАГОДАРНОСТИ}

Исследование финансируется Комитетом науки Министерства образования и науки Республики Казахстан (программа целевого финансирования BR10965247 «Изучение фактоpoв, особенностей и динамики демографических процессов, миграции, урбанизации в Казахстане, разработка цифровых карт и прогнозов») 
терпретацию этого термина с особым акцентом на SWOT-факторы. Были описаны основные цифровые сервисы в Москве, Нур-Султане и Алматы. Результаты SWOT-анализа показали существенные различия в том, как три столицы реализуют свои проекты умных городов, а также схожие проблемы, с которыми они сталкиваются, такие как институциональные барьеры, отсутствие стандартов, финансовые ограничения, нехватка произведенного внутри страны оборудования и программного обеспечения, высококвалифицированных кадров и частных инвесторов.

Выводы. Среди факторов, влияющих на реализацию проектов умных городов в трех городах, можно отметить пандемию COVID-19, которая, вероятно, будет стимулировать цифровую трансформацию как в краткосрочной, так и в долгосрочной перспективе.

\section{ДЛЯ ЦИТИРОВАНИЯ}

Urdabayev, M.T., \& Utkelbay, R.E. (2021) SWOT analysis of smart city projects in capital cities of Russia and Kazakhstan. R-economy, 7(4), 235-243. doi: $10.15826 /$ recon.2021.7.4.021

\section{Introduction}

The increasing informatization in all spheres of life in Russia and Kazakhstan is part of the global trend which encompasses the digital transformation of cities. In Russia, as part of the 'Digital Economy' program developed by the Ministry of Communications, it is planned to create over 50 smart cities (Akimova, 2019). In Kazakhstan, smart city projects are supported and initiated by the Ministry of Digital Development, Innovations and Aerospace Industry. To develop a more standardized approach for smart city building, in 2019, the Reference Standard of Smart Cities of the Republic of Kazakhstan was adopted.

Smart city projects generally comprise the creation of two types of infrastructure: hard infrastructure (built environment and utilities such as roads, bridges, etc.), which is self-sustaining and resilient to negative impacts, and soft infrastructure (services, human capital and institutions that cultivate it), which holds more potential for fostering innovation. A city develops and modernizes the infrastructure of both types in order to meet the needs of urban communities (Demidov, 2019).

In cities of different types, smart city projects may acquire different characteristics. In this study, we are going to focus on capital cities: the research into the smart city projects and approaches underlying them in national capitals can provide us with some interesting insights as these urban agglomerations concentrate a large part of the population and economic resources and act as centres of political and economic decision-making. Due to the complexity and diversity of the socio-economic processes concentrated in capital cities, their authorities are generally more inclined to spur innovation and implement digital systems for urban development manage- ment. Smart city projects in Russia and Kazakhstan are of special interest as they have a lot in common in terms of population distribution patterns, spatial configurations and the role they play in the socio-economic development of their countries.

This study aims to conduct a strategic analysis of smart city projects in capital cities of Russia and Kazakhstan - Moscow (Russia), Almaty and Nur-Sultan (Kazakhstan). Almaty was included in the sample because it has lost its status of national capital only recently, and therefore still retains most of its characteristics, which provides ground for comparison between the old and new Kazakh capitals.

The above-described research objective determined the choice of the following research tasks: first, we are going to systematize the approaches to defining the term 'smart city'; second, we will characterize the key digital services that are currently in use in Moscow, Nur-Sultan and Almaty; and, finally, we will conduct a SWOT analysis of smart city projects in Moscow, Almaty and Nur-Sultan, compare and summarize the results.

\section{Theoretical framework and methodology}

The notion of smart city emerged and entered public discourse in the late 1990s. There is, however, no uniform understanding of what constitutes a smart city (Kupriyanovsky, 2016). Robert Hall points out that a smart city should be a safe, secure, environmentally green and efficient place for living. All structures of such a city (power, water, transportation, sewage) should be designed, constructed, and maintained by making use of an advanced infrastructure based on networks, electronic and sensors (Robert E. Hall, 2000). 
The British Standards Institute (BSI) defines the term 'smart city' as a built environment characterized by 'the effective integration of physical, digital and human systems ... to deliver sustainable, prosperous and inclusive future for its citizens" (BSI, 2020).

The UN's Economic Commission for Europe defines a smart city the following way: 'A smart sustainable city is an innovative city that uses information and communication technologies (ICTs) and other means to improve quality of life, efficiency of urban operation and services, and competitiveness, while ensuring that it meets the needs of present and future generations with respect to economic, social, cultural and environmental aspects' (Economic and Social Council, 2015).

A similar viewpoint is expressed by Hall et al.: in their view, a smart city is 'a city that monitors and integrates conditions of all of its critical infrastructures, ...can better optimize its resources, plan its preventive maintenance activities, and monitor security aspects while maximizing services to its citizens' (Hall et al., 2000, p. 2).

Data collection in smart cities through sensors, cameras and other devices helps maintain stable operation of utility services, urban landscaping, healthcare and transport infrastructure (Kuznetsova, 2019).

Urban scholar Murunov defines a smart city as 'a comfortable urban environment which has a positive impact on people's mental health' (Murunov, 2018). In other words, a modern, technologically advanced city is a city that meets all the modern requirements and conditions.

Odendaal believes that information technologies widely used in smart cities contribute to these cities' uninterrupted progress and improvement of the standards of life of their citizens (Odendaal, 2016). Nam \& Pardo point out the human dimension of the smart city concept: 'A smart city is a humane city that has multiple opportunities to exploit its human potential and lead a creative life' (Nam \& Pardo,2011, p.285). Giffinger et al. emphasize citizen participation as a crucial factor of a smart city's steady development (Giffinger et al., 2010).

The definition of a smart city proposed by $\mathrm{P}$. Nijkamp \& K. Kourtit is worthy of special attention (Kourtit \& Nijkamp, 2012): they believe that smart cities depend on creative and knowledge resources to maximize their innovation potential through strategies aimed at reaching the desired levels in the environmental, transport, economic, social and other 'smartness' performance indicators.

Nunes et al. offer a more practical approach to the smart city concept, which, in their view, is based on the interactions between several clusters within the city itself (Nunes et al., 2021). They propose a model for decision-making based on cognitive mapping to identify the determinants of smart city success from different areas. The proposed methodological framework provides a comprehensive understanding of a smart city (Nunes et al., 2021).

Rozario et al. (2021) consider the modern focus of smart cities from three angles: infrastructure engineering, information technology and people-centric management. These scholars seek to draw attention to the 'need for developing smart cities with a holistic approach involving multiple perspectives rather than a siloed emphasis on technology alone' (Rozario et al., 2021). They also highlight the fact that the concept of smart city should be more people-centric and that one of the most important purposes of smart cities is 'the satisfaction of those who dwell in them-the citizens' (Rozario et al., 2021).

We believe that innovation lies at the core of the smart city concept. In other words, a smart city is a city where comprehensive technical solutions are implemented and strategies to enhance resource use efficiency and ensure the delivery of high-quality services are realized. Another important aspect of smart cities is that they are aimed at creating a more liveable, resilient, and sustainable urban environment for residents at present and in the future.

Methodologically, this study relies on the method of SWOT analysis, which is a popular strategic analysis tool. It assesses internal and external factors dividing them into four categories: strengths, weaknesses, opportunities and threats. These method of strategic analysis was chosen because it was best suited for the purpose of this study: to systematize and summarize diverse quantitative and qualitative empirical data. The results of such analysis provide valuable evidence for managerial decision-making (Baskakova et al., 2020).

The study is based on the evidence provided by academic publications and professional media publications on the topic, national and local official documents, and materials reflecting expert discussions about the problems of smart city development in Russia and Kazakhstan. 


\section{Results and Discussion}

\section{Implementation of the Smart City Project in Moscow}

In Moscow, the Smart City Project started in 2011. So far, the following smart services have been introduced. The online voting platform 'Active Citizen' was launched in 2014. This platform can be used for conducting local referendums. According to the statistical data, in 2019 the platform had over 2 million registered users; by that time, 2,710 elections had been held and over 86 million votes had been registered (Ptitsyn, 2019). The platform 'Active Citizen' is also suitable for conducting surveys among the citizens of Moscow to assess their satisfaction with parks and green spaces, public transport routes, and so on (Ivanova \& Karagulyan, 2021).

Another platform, 'Our City', is also very popular among the citizens of Moscow - it facilitates citizens reporting local problems and sending non-emergency requests to municipal services. This platform has over 1 million registered users.

Platform Crowd4 was created to enhance citizen participation. This platform has over 130 thousand registered users. Over 84 thousand initiatives have been registered, some of which have been accepted by governmental agencies.

The development of smart city technologies is supported by the Department of Information Technologies, which integrates all the ITs into a single system. Most public services in Moscow can now be accessed online. All of the above creates a solid foundation for further development of the smart city system in Moscow (Chudiniva \& Afonina, 2018).

Most of the initiatives related to the smart city project are associated with the capital's transport infrastructure. Moscow currently has over 2,000 sets of traffic signals, 3,500 traffic detectors and 2,000 traffic cameras. If the cameras or other devices for traffic control have detected any rule violations, the data are transmitted to the Situation Centre of the Traffic Organization Centre to detect and fine road traffic violations (Golubev, 2018).

Moreover, video surveillance systems help the authorities get a better understanding of how certain measures may influence the whole traffic situation: for example, how the traffic flow will change if a street is closed to cars or whether the number of cars will fall if a one-way system is introduced. Babakin (2019) believes that intelligent transportation systems can be very efficient in reducing the number of road accidents. In Moscow, such innovations have led to a $13 \%$ increase in the speed of traffic flow.

In Moscow, there is ongoing construction of smart buildings and smart water supply systems. Smart meters are being installed. Buildings are equipped with smart energy meters for more efficient energy consumption (Pimenov et al., 2020).

The project aimed at providing free WiFi coverage in streets and recreational public spaces has been under way since 2012. Among other things, its outcomes included the installation of free WiFi hotspots at educational institutions and transport stops. As a result of the government's efforts, Moscow now ranks second in the world for free WiFi and connectivity. Free WiFi hotspots are also available in locations which are popular both with locals and tourists such as VDNKh, Moscow Zoo, libraries, and cultural centres (Salkuti, 2021).

Moscow government makes a great contribution to the progress of the smart city project by attracting investors. An important part of the project is the public-private partnerships (PPPs), where all project participants are actively cooperating with various tech companies. Public participation in decision-making is also encouraged.

Table 1 below summarizes the strong and weak points, threats and opportunities of the smart city project in Moscow.

\section{Implementation of the Smart City Project in Nur-Sultan}

Nur-Sultan can be described as a competitive, steadily growing city with moderately developed infrastructure, a well-developed health care system, high-quality education, comfortable and sustainable urban environment adapted to the adverse impacts of the local climate (Yuloskov et al., 2021). The city has a number of well-performing clusters and a developed innovation eco-system. The level of entrepreneurial activity of local inhabitants is also quite high. Nur-Sultan was among the first Kazakh cities to implement digital technologies for urban management.

It should be noted that most of such projects in Kazakhstan are realized through PPPs. Quite illustrative in this respect is the creation of a situation centre which collects and processes data from surveillance cameras and helps the local authorities communicate more efficiently with the citizens. The inhabitants of Nur-Sultan enjoy ac- 
cess to a mobile application and a digital platform for online public services.

Nevertheless, despite the latest developments in the city driven by technological progress, it faces a number of problems such as the lack of formalized digital architecture and means of ensuring data security. Over $25 \%$ of databases have limited access and they are updated once a month at most (Lebedev, 2019). Another problem is that akimat officials often lack the necessary digital skills and competencies, which has a negative impact on the implementation of smart technologies for the management of the urban infrastructure.

Other problems that need to be addressed include the lack of funding, the lack of domestically produced digital products, the lack of investors and PPPs. The transportation sector also faces some challenges. Local educational institutions offer few digital technologies programmes and courses, which results in the shortage of qualified specialists in this field. The results of SWOT-analysis of Nur-Sultan are shown in Table 2 below.

\section{Implementation of the Smart City Project in Almaty}

Almaty is the largest city in Kazakhstan characterized by high levels of socio-economic development, environmental sustainability, demographic potential and secure communication channels ${ }^{1}$. The city is increasingly reliant on digital tools to build a set of services such as an integral fire services command and control system, a system to improve security at schools, and so on. There are also projects for water quality monitoring and for environmental data capture (Turgel, Bozhko, \& Pandzhiyeva, 2020).

Speed cameras and traffic sensors have been quite effective at reducing the number of road accidents. In 2020, the number of road deaths fell by $48 \%$ in comparison with 2019 . Digital solutions have also helped cut down on emergency response time by 20\% (Yuloskov et al., 2021). The city's key digital projects include the creation of an automated traffic monitoring

${ }^{1}$ Golubev, M. (2018). 'Big University' City: Expert-Sibir, 30/34, 16-18. (In Russ.)

Table 1

SWOT-analysis of the smart city project in Moscow

\begin{tabular}{|c|c|}
\hline Strengths & Weaknesses \\
\hline 1. Capital of Russia and the largest city in the country & $\begin{array}{l}\text { 1. High project costs due to the need to purchase software } \\
\text { from foreign companies }\end{array}$ \\
\hline 2. High degree of innovation & 3. Lack of public awareness of the project's advantages \\
\hline 3. Sustainable infrastructure and environment & 3. Long payback period \\
\hline 4. High population growth rates & $\begin{array}{l}\text { 4. The city hasn't accumulated sufficient technical expertise } \\
\text { of its own }\end{array}$ \\
\hline 5. Secure communication channels & $\begin{array}{l}\text { 5. Vulnerability to cyber security threats and insecure data } \\
\text { storage }\end{array}$ \\
\hline 6. Free WiFi coverage in streets and public places & 7. Lack of project funding \\
\hline $\begin{array}{l}\text { 7. Advanced modern technologies: sensors, devices and } \\
\text { measuring instruments }\end{array}$ & \multirow[t]{2}{*}{$\begin{array}{l}\text { 7. Lack of resources, especially highly qualified human } \\
\text { resources }\end{array}$} \\
\hline 8. Video surveillance cameras for monitoring road traffic & \\
\hline Opportunities & Threats \\
\hline 1. Accumulation of technical expertise & 1. Lack of investors \\
\hline 2. Lower car accident rates and traffic violation rates & 2. Lack of domestically produced software solutions \\
\hline 3. Reduced energy, heating and water supply costs & $\begin{array}{l}\text { 3. Cyber security threats and vulnerabilities of the city's } \\
\text { integral information system }\end{array}$ \\
\hline 4. Faster emergency response & 4. Outdated planning solutions \\
\hline 5. Improved performance of urban facilities & 5. Aggravation of transportation problems \\
\hline 6. Emergency response management & 6. Increased environmental pressures \\
\hline 7. Improved security of systems & 7. Urban identity crisis \\
\hline
\end{tabular}


system, monitoring system for landslide hazard assessment, emergency alert systems, lifesaving mobile application '102', and some others (Ptitsyn, 2019). The akimat and other government bodies are working together to collect the data on crime rates and traffic violation rates to devise preventive measures against public security breaches.

Despite the array of advantages the city holds, there are also some challenges that need to be addressed. The main problems Almaty faces is the lack of coordinated goal-setting and strategy-making regarding the city's smart development, the lack of funding, and obsolete technological systems. Thus, the city needs to decommission obsolete automated models and stimulate PPPs with companies capable of improving Almaty's digital system (Salkuti,2021).
Almaty holds a great potential for smart development but how soon these technologies will be put into use largely depends on the decision-making process of the akimat, efficient strategic planning and effective PPPs. The results of SWOT-analysis of the situation in Almaty are shown in Table 3 below.

\section{Conclusion}

Our SWOT analysis took into account the following characteristics of a smart city: innovation; maintenance of improved living environment at present and in the future; comprehensive technological solutions; efficient resource management; and delivery of high-quality services. The comparative analysis for three capital cities (Moscow, Nur Sultan, and Almaty) has brought to light some significant differences in the way they implement

SWOT analysis of the smart city project in Nur-Sultan

Table 2

\begin{tabular}{|l|}
\hline \multicolumn{1}{|c|}{ Strengths } \\
\hline $\begin{array}{l}\text { 1. Capital of Kazakhstan - a competitive, steadily growing } \\
\text { city }\end{array}$ \\
\hline 2. Moderately developed urban infrastructure \\
\hline $\begin{array}{l}\text { 3. Integrated city with a developed healthcare system, } \\
\text { high-quality education, comfortable and sustainable urban } \\
\text { environment adapted to the adverse impacts of the local } \\
\text { climate }\end{array}$ \\
\hline
\end{tabular}

4. Efficient transport system

5. Range of globally competitive clusters

6. Developed innovation eco-system

7. High entrepreneurial activity
1. High financial costs due to the lack of domestically produced software

3. Moderately developed digital infrastructure

3. Lack of data access and transparency

4. Akimat officials lacking the necessary digital skills and competencies

5. Long payback period

6. Lack of funding

7.Insufficient development of the urban environment; barriers to the city's spatial development (regulatory barriers, poor planning and the opportunistic approach to the implementation of urban planning policies)

8. Lack of formalization of the digital infrastructure and the lack of detailed cybersecurity strategies

\section{Opportunities}

1. The city's advantageous position in comparison to deliver on its smart development goals

2. Greater access to resources due to the city's status

3. Digital technologies contributing to economic performance

\section{Threats}

1. Lack of investors and PPPs

2. Lack of domestically produced software and high costs of imported software and equipment

3. Unbalanced economic growth and falling living standards

4. High levels of development of different sectors of economy 5 . Increasing competition for resources between the regions of Kazakhstan

\begin{tabular}{|l|}
\hline 5. High level of the system's security \\
\hline 6. Efficient management of the urban infrastructure
\end{tabular}

5. Aggravation of transportation problems

6. Budget risks associated with shrinking government subsidies

Source: compiled by the authors from the data provided by the official web-site of Nur-Sultan akimat (Smart City. Retrieved from: https://astana.gov.kz/ru/page/smart (Accessed: 25.10.2021). (In Russ.)) 
their smart city projects (Danilina, Slepnev, 2018). Nevertheless, these cities are facing similar problems, such as the lack of funding, domestically produced equipment and software, highly qualified human resources, and private investors.

For a more sustainable positive result, smart city projects should include optimization of ser- vices, expansion of the range of digital services, stimulation of PPPs, and cooperation with tech organizations. Other factors contributing to the success of smart city projects are an efficient management system, transparency, innovative methods of capital raising, a feedback loop in Public Relations, and developed digital competencies and skills of

SWOT analysis of the smart city project in Almaty

\begin{tabular}{|l|}
\hline \multicolumn{1}{|c|}{ Strengths } \\
\hline $\begin{array}{l}\text { 1. The largest city in Kazakhstan with population over } \\
\text { 1.98 million. }\end{array}$ \\
\hline 2. Good socio-economic conditions \\
\hline 3. Environmental sustainbility \\
\hline 4. High demographic potential \\
\hline 5. Integral system for improving school security \\
\hline 6. Emergency alert system \\
\hline 7. Secure communication channels \\
\hline 8. Integral fire services command and control system \\
\hline 9. Emergency call centres integrated into one service - '112' \\
\hline $\begin{array}{l}\text { 10. Advanced modern technologies: sensors, devices and } \\
\text { measuring instruments }\end{array}$ \\
\hline
\end{tabular}

11. Free WiFi coverage in streets and public places

12. System of automated monitoring of landslide hazard assessment with sensors being installed in landslide-prone areas in mountanous regions

\begin{tabular}{|l|}
\hline \multicolumn{1}{|c|}{ Opportunities } \\
\hline 1. Emergency alert system \\
\hline 2. Integral system of water use monitoring and reporting \\
\hline 3. Less road accidents \\
\hline 4. Faster response to emergency situations \\
\hline
\end{tabular}

5. Lower energy, heating and water supply costs

6. Transition to smart city governance

7. Human capital development

8. Creation of an innovation eco-system

9. Digitalization of different sectors of economy to increase labour productivity and stimulate growth

10. Increase in the number of public servants capable of working remotely

11. Emergency response management

12. Modernization of obsolete systems

13. Interdepartmental cooperation

14. Creation of an integral data storage centre

Source: compiled by the authors from the web-site of 'Smart Almaty' Concept (Concept - Smart Almaty - Effective Innovations. Retrieved from: https://smartalmaty.kz/smart.html (Accessed: 25.10.2021). (In Russ.))

1. High financial costs

2. High pollution levels

3. Poor infrastructure

4. Depreciation of the residential housing stock and utility services communications

5. Surging crime rates and car accident rates

6. Long payback period

7. Lack of the city's own technical expertise

8. Shortage of personnel in the Department of Digitalization

9. Lack of funds and qualified workforce for project realization

10. Complicated procedure for the approval of technological investment projects, which slows down the process of hardware and software procurement and implementation

11. Digital skills shortage among city government officials

1. Complicated procedure for the approval of technological investment projects, which slows down the process of hardware and software procurement and implementation

2. Lack of investors and PPPs

3. Lack of domestically produced software solutions

4. Aggravation of traffic congestions and increasing crime rates

5. Outdated systems for document management

able 3 
municipal government officials. Cities also need to ensure effective coordination of projects and invest in the replacement of obsolete systems.

The main institutional barrier impeding the success of smart city projects in Russia is the lack of standards and legislation to regulate the testing of new innovative products and technologies by actors of the digital economy (Kolobova, 2020). Russian cities have yet to accumulate sufficient technical expertise in such spheres as management of transport infrastructure, energy management control systems, control systems for heating and water supply, smart medical systems, remote patient monitoring systems, etc (Vodk, Ulyov, Kubina, 2021).

It should be noted that since the onset of the pandemic, there has been a tremendous surge in digital activity, in particular in the use of digital technologies for urban governance. As humanity continues struggling with the pandemic, its effect on urban life will be long-lasting and will include the rapid spread of digital technologies (e.g. digital tools for delivering online services, for monitoring and control).

\section{References}

Akimova, O.E. (2019). Unique Advantages of the Smart City Concept in the Context of Development of the Modern Economic-Strategic Planning, Kreativnaya ekonomika, 8, 1521-1528. (In Russ.).

Babakin, A.V. (2019). Digital Economy and Industry 4.0: Problems and Prospects: Conference Proceedings edited by Prof. A.V. Babkin. St. Petersburg, 1, 685

Baskakova, I.V., Podymova, A.S., Turgel, I.D., \& Balandina, M.S. (2020). Evaluation of the Impact of HIV/AIDS on Living Standards in Regions. Economy of Region, 16(1), 114-126. (In Russ.). doi: $10.17059 / 2020-1-9$

BSI (British Standards Institution). Smart Cities Overview-Guide. Retrieved from: https:// www.bsigroup.com/en-GB/smart-cities/Smart-Cities-Standards-and-Publication/PD-8100-smartcities-overview/

Chudiniva, O., \& Afonina, M. (2018). Formation of 'urban planning' indicators for 'smart City' concept (on the example of SKOLKOVO, Moscow). MATEC Web of Conferences, 170, P. 2021. A Retrieved from: https://pdfs.semanticscholar.org/d9a7/becd17585ca7be6509592a60104b7cb620cd. pdf? ga $=2.167613053 .293620202 .1637843227-545392319.1637319312$

Danilina, N., \& Slepnev M. (2018). Managing smart-city transportation planning of 'parkand-ride' system: Case of Moscow metropolitan. IOP Conference Series: Materials Science and Engineering. 365(2), p. 22002. Retrieved from: https://iopscience.iop.org/article/10.1088/1757-89 9X/365/2/022002/pdf

Demidov, M. (2019). Artificial Intelligence in Big City Communications. Kommunalny kompleks Rossii, 7, 42-45. (In Russ.).

Giffinger, R. (2010). Smart cities ranking: An effective instrument for the positioning of the cities. Retrieved from: http://www-cpsv.upc.es/ace/Articles_n10/Articles_pdf/ACE 12 SA 10.pdf

Golubev, M. (2018). 'Big University' City: Expert-Sibir, 30/34, 16-18. (In Russ.).

Hall Robert E., Bowerman B., Braverman J., Taylor J., Todosow H., \& Wimmersperg U. (2000). The Vision of A Smart City. Resented at the 2nd International Life Extension Technology Workshop Paris, France Retrieved from: https://www.osti.gov/servlets/purl/773961

Hall P. (2000). Creative cities and economic development. Urban Studies, 37(4), 639-649. doi: $\underline{10.1080 / 00420980050003946}$

Ivanova, S.A., \& Karagulyan, E.A. (2021). Smart City from the Perspective of Rankings. Voprosy innovatsionnoy ekonomiki, 2, 641-656. doi: 10.18334/vinec.11.2.112080 (In Russ.).

Karasev, O.I., \& Krivtsova, A.O. (2019). Factors of Efficient Urban Transport Policy. Ekonomika i upravlenie, 2, 22-28. (In Russ.).

Kolobova, S. (2020). Renovation of Moscow as a Subprogram of Creation of a Creative City. IOP Conference Series: Materials Science and Engineering. 753(6), 62003. Retrieved from: https:// iopscience.iop.org/article/10.1088/1757-899X/753/6/062003/pdf

Kourtit, K., \& Nijkamp, P. (2012). Smart Cities in the Innovation Age. Innovation: The European Journal of Social Science Research, 2, 93-95. doi: 10.1080/13511610.2012.660331

Kupriyanovsky, V.P., Bulancha, S.A., Chernykh, K.Y., \& Dobrynin, A.P. (2016). Smart Cities as 'Capitals' of Digital Economy. International Journal of Open Information Technologies, 4, 41-52. (In Russ.). 
Kuznetsova, D.D. (2019). Automated Systems for Quality Control of Urban Road and Transport Infrastructure. Industrial Automated Command and Control Systems, 9, 11-17. (In Russ.).

Lebedev, A. (2019). Smart Transport as Part of a Smart City Technological Eco-System. Sistemy bezopasnosti, 4, 26-28. (In Russ.).

Murunov S. (2018). Comfortable Urban Environment. (In Russ.).URL: https://www.academia. edu/38589114/Комфортная_городская_среда

Nam T. \& A. Pardo T., (2011). Conceptualizing smart city with dimensions of technology, people, and institutions. Proceedings of the $12^{\text {th }}$ Annual International Conference on Digital Government Research, DG.O 2011, College Park, MD, USA, June 12-15. doi: 10.1145/2037556.2037602

Nunes, S.A.S., Ferreira, F.A.F., Govindan, K., \& Pereira, L.F. (2021). Cities go smart! A system dynamics-based approach to smart city conceptualization. Journal of Cleaner Production, 313, 127683. Retrieved from: https://www.sciencedirect.com/science/article/pii/S0959652621019016? via=ihub

Odendaal N (2016). Smart city: Neoliberal discourse or urban development tool? The Palgrave handbook of international development. (pp. 615-633). Palgrave Macmillan, London. Retrieved from: https://scholar.google.com/citations?view op=view citation\&hl=en\&user=AeAAlAoAAAAJ\&citation_for_view=AeAAlAoAAAAJ:ghEM2AJqZyQC

Pimenov, P., Gordeev, M., Petrova, N., \& Fedorova, R. (2020). The problem of assessing the economic effect of the smart city concept introduction in Russia. E3S Web of Conferences, vol. 208. (pp. 3028). Retrieved from: https://www.e3s-conferences.org/articles/e3sconf/pdf/2020/68/e3sconf ift2020 03028.pdf

Ptitsyn, N. (2019). Secure City in a Private Cloud. Creation of a National-Level Operator. Sistemy bezopasnosti, 4, 24-25. (In Russ.).

Rozario, S. D., Venkatraman, S., Marimuthu, M., Khaksar, S. M. S.\& Subramani, G. (2021). Creating smart cities: A review for holistic approach. Applied System Innovation, 4(4), 70. Retrieved from: https://www.mdpi.com/2571-5577/4/4/70/htm

Salkuti, S.R. (2021). Smart cities: Understanding policies, standards, applications and case studies. International Journal of Electrical and Computer Engineering, 11(4), 3137-3144. Retrieved from: http://ijece.iaescore.com/index.php/IJECE/article/view/22852/14936

Turgel, I.D., Bozhko, L.L., \& Pandzhiyeva, V.T. (2020). Cluster policies of large cities in Russia and Kazakhstan. R-Economy, 6(1), 28-39. doi: 10.15826/recon.2020.6.1.003

Vodk, J., Ulyov, D., \& Kubina, M. (2021). Advanced technologies and their use in smart city management. Sustainability (Switzerland), 13(10), 5746. Retrieved from: https://www.mdpi. com/2071-1050/13/10/5746/htm

Yuloskov, A., Bahrami, M.R., Mazzara, M., \& Kotorov, I. (2021). Smart cities in russia: Current situation and insights for future development. Future Internet, 13(10), 252. Retrieved from: https:// www.mdpi.com/1999-5903/13/10/252

\section{Information about the authors}

Marat T. Urdabaev - doctoral student, Higher School of Economics and Business, Al-Farabi Kazakh National University (71 Al-Farabi Ave., Almaty, 050040, Republic of Kazakhstan); email: marat.urdabayev@ieconom.kz

Rysbek E. Utkelbay - doctoral student, Faculty of International Relations, Al-Farabi Kazakh National University (71 Al-Farabi Ave., Almaty, 050040, Republic of Kazakhstan); e-mail: u.rys@mail.ru

ARTICLE INFO: received October 11, 2021; accepted November 30, 2021

\section{Информация об авторах}

Урдабаев Марат Тагайбекович - докторант, Высшая школа экономики и бизнеса, Казахский национальный университет имени аль-Фараби (050040, г. Алматы, пр. альФараби, 71); e-mail: marat.urdabayev@ieconom.kz

Уткелбай Рысбек Ерланулы - докторант, Факультет международных отношений, Казахский национальный университет имени аль-Фараби (050040, г. Алматы, пр. альФараби, 71); e-mail: u.rys@mail.ru

ИНФОРМАЦИЯ О СТАТЬЕ: дата поступления 11 октября 2021 г.; дата принятия к печати 30 ноября 2021 г. 